\title{
MEGJEGYZÉSEK A KECSKEMÉT KÖRNYÉKI ETNIKAI VIZSGÁLATOKKAL KAPCSOLATBAN
}

\author{
Farkas L. Gyula és Molnár Erika
}

Szegedi Tudományegyetem, Embertani Tanszék, Szeged

Farkas L. Gy., Molnár E.: Remarks on the ethnical investigations of Kecskemét and its surroundings. The preparation of a monograph on the city of Kecskemét and its surroundings has begun in the Katona József Museum of Kecskemét under the direction of Zsuzsanna Bereznai ethnographer, editor in chief of the upcoming book.

One chapter of the monograph will be dedicated for the results of the anthropological investigation of the subadult and adult populations. The editor in chief entrusted one author of the present study with the preparation of this chapter and made the data sheet of the previous anthropological study on the adult population of Kecskemét and is surroundings available. The previous study was performed by Gyula Henkey. During the evaluation of the data it turned out that not all data sheet can be used, because the date of birth and date of inspection were incompletely recorded in some cases. Beside this data of the juveniles occur in several cases among the data of the adult population. The examined morphological traits are recorded in an unreadable form. As a result of these, the evaluation cannot be made in the usual manner.

Keywords: Ethnical investigation; Adult population; Kecskemét; Gyula Henkey; Re-evaluation of the data.

\section{Bevezetés}

1970 óta számos település monográfiája jelent meg és azok között szerencsés módon sok esetben lehetőség nyílt arra is, hogy az adott település felnőtt lakosságának antropológiai jellemzését konkrét adatgyüjtések alapján ismertetni lehessen. Ilyen jellegü monográfia elkészítését tervezi a kecskeméti Katona József Múzeum; a szerkesztői és szervező munkát Bereznai Zsuzsanna néprajzos muzeológus végzi. A monográfia egyik fejezetében lehetőség van a fiatalkorúakon és felnőtteken a Kecskeméten és környékén korábban végzett antropológiai vizsgálatok eredményeinek az ismertetésére is (Farkas 2016).

A felnőttek antropológiai jellegeinek értékelésének alapját a kecskeméti múzeumban levő és Henkey Gyula által 9 településen gyüijtött adatok képezték. Ezeknek a vizsgálati lapoknak a feldolgozása során azonban néhány, az értékelést megnehezítő körülmény adódott.

$\mathrm{Az}$ életkorok megállapításánál nehézséget jelentett az a tény, hogy az adatgyüjtő lapokon a vizsgált személy pontos születési idejére, valamint a pontos vizsgálati időpontra vonatkozó feljegyzések hiányosak. Négy település (Fülöpszállás, Szabadszállás, Ókécske, Orgovány) esetében a vizsgált személyek pontos születési dátuma és a vizsgálatok időpontja nincsenek feltüntetve. Bugac, Kunszállás, Lászlófalva, Szalkszentmárton településeknél az adatgyüjtő lapokon csak a megvizsgáltak születési ideje, Újkécske esetében pedig csak a születési év van feljegyezve (megemlítendő, hogy Lászlófalva község 1952-ben alakult Kecskemét Alsószentkirály és Felsőszentkirály településekből, 1987 óta a község neve Szentkirály). Minden esetben egész szám jelzi a 
lapokon a vizsgált egyén életkorát, ami arra utal, hogy Henkey az életkort bemondás alapján jegyezte fel. Emiatt a megvizsgált személy pontos életkorát nem lehet decimális táblázattal kiszámítani. Az etnikai vizsgálatoknál az egyéneket általában a 20-40, 41-60 és 61 évesnél idősebbek korcsoportjába szoktuk besorolni. Az előzőkben említett, pontos születési időpont hiánya miatt nem lehet egyértelműen meghatározni, hogy ki tartozik a 20, 40, 41, 60, 61 évesek korcsoportjába. Henkey a fülöpszállásiak és szabadszállásiak (Henkey 1961, 1962-63), Mándoki a szabadszállásiak esetében (Mándoki 1961) a 20 évesnél fiatalabbakat is bevonta az értékelésbe, ami szakmai szempontból helytelen.

Henkey feljegyezte a morfológiai jellegeket is, azokat azonban az olvashatatlan írás miatt nem lehet értékelni.

\section{Vizsgált anyag és alkalmazott módszerek}

Az előzőek figyelembevételével a rendelkezésre álló és értékelésre alkalmas vizsgálati lapok száma eltérő (1. táblázat).

1. táblázat. A megvizsgált felnőttek megoszlása települések és nemek szerint. Table 1. Number of the examined adult individuals by sex and residence.

\begin{tabular}{|c|c|c|c|c|}
\hline \multirow[b]{2}{*}{ Település - Residence } & \multicolumn{2}{|c|}{ Megvizsgáltak - Examined } & \multicolumn{2}{|c|}{ Értékeltek - Evaluated } \\
\hline & Férfiak - Males & Nök - Females & Férfiak - Males & Nők - Females \\
\hline Bugac & 103 & 104 & 103 & 104 \\
\hline Fülöpszállás & 250 & 250 & 233 & 222 \\
\hline Kunszállás & 161 & 160 & 159 & 157 \\
\hline Lászlófalva & 100 & 111 & 100 & 111 \\
\hline Ókécske & 123 & 115 & 123 & 110 \\
\hline Orgovány & 22 & 29 & 21 & 27 \\
\hline Szabadszállás & 234 & 212 & 226 & 188 \\
\hline Szalkszentmárton & 143 & 84 & 136 & 82 \\
\hline Újkécske & 118 & 117 & 116 & 111 \\
\hline Összesen - Total & 1254 & 1182 & 1217 & 1112 \\
\hline
\end{tabular}

A felnőttek antropológiai jellemzéséhez a Henkey Gyula által gyüjtött, a kecskeméti Katona József Múzeumban levő és részünkre átadott vizsgálati anyagból kilenc település lakosságára vonatkozó adatgyüjtő lapokat értékelhettük. Ezek a települések a következők: Bugac, Fülöpszállás, Kunszállás, Lászlófalva, Ókécske, Orgovány, Szabadszállás, Szalkszentmárton, Újkécske. Az adatgyüjtő lapok közül csak azokat vettük figyelembe, amelyek 20 éves vagy annál idösebb egyénekre vonatkoznak.

Milyen következtetések vonhatók le az említettekböl? Elöször is az, hogy ez az értékelési mód nem teszi lehetővé a mások által közölt és decimális életkor alapján felosztott csoportokkal való összehasonlítást. Erre csak úgy lenne lehetőség, ha a korábbi, felnőttekre vonatkozó adatgyüjtések esetében a fentiekben jelzett korcsoportok adatait szintén összevonjuk. Másrészt egyes jellegeknél az életkor elörehaladásával összefüggő változások átlagai kissé torzulnak. Az ember testmagasságánál a gerincoszlop görbülése, az arcmagasságnál a fogak kihullása és pótlásának hiánya miatt a korábbi életkorokhoz képest az idősebb korban kisebb értékeket kapunk. Végül az általunk értékelt kilenc település esetében lehetőség van az összehasonlításra, mivel a korcsoportok esetében az értékelés azonos módon történt. 
A megállapított méretekből településenként és nemek szerint kiszámítottuk a megvizsgált egyének számát (n), jellegenként a legkisebb és legnagyobb értéket (variációs terjedelem, Min. és Max.), az aritmetikai átlagot ( $\bar{x}$ ) és a szórást (s). Utóbbi - a jellegtől függően - annál nagyobb, minél nagyobb a méret esetében a legkisebb és legnagyobb érték közötti eltérés (2. táblázat).

Az egyes jellegek és relatív méretek (indexek) esetében az egyes szerzők (Lebzelter, Saller, Martin) által meghatározott felosztás szerint (Farkas 1973) csoportosítottuk az adatokat (3-4. táblázat).

\section{Vizsgálati eredmények és értékelésük}

A férfiak és nők jellegeit az 5. táblázatban feltüntetett átlagok alapján jellemezzük. Megemlítjük, hogy az átlag kiemeli a közös tulajdonságokat, de elfedi a különbségeket. Ezek figyelembe vételével a férfiakat és nőket az átlagok alapján következő módon jellemezhetjük:

Férfiak: testmagasságuk nagyközepes, fejük hosszú, széles, homlokuk széles, arcuk széles és középmagas, állkapcsuk nagyon széles. A relatív méretek szerint fejük rövid (brachycephal), arcuk széles (euryprosop), orruk keskeny (leptorrhin, 2. táblázat).

Nők: termetük nagyközepes, fejük hosszú, homlokuk széles, arcuk széles és középmagas, az állkapcsuk széles. A relatív méretek szerint fejük rövid (brachycephal), arcuk széles (euryprosop), orruk keskeny (leptorrhin, 2. táblázat).

2. táblázat. Az összevont minta statisztikai paraméterei nemek és jellegek szerint. Table 2. Statistical parameters of the merged sample by sexes and traits.

\begin{tabular}{|c|c|c|c|c|c|c|c|}
\hline \multirow[b]{2}{*}{ Jelleg - Traits } & \multicolumn{3}{|c|}{ Férfiak - Males } & \multicolumn{4}{|c|}{ Nők - Females } \\
\hline & $\mathrm{n}$ & $\overline{\mathrm{X}}$ & Min. - Max. & $\mathrm{n}$ & $\overline{\mathrm{x}}$ & $\mathrm{s}$ & Min. - Max. \\
\hline Termet - Stature (cm) & 1212 & $167,26,42$ & $148,8-192,8$ & 1107 & 156,3 & 5,89 & $137,7-175,2$ \\
\hline Legnagyobb fejhossz - Head length (mm) & 1217 & $188,86,08$ & $151-212$ & 1112 & 180,4 & 5,08 & 159-201 \\
\hline ad breadth (mm) & 1217 & $158,85,26$ & 139-178 & 1112 & 153,7 & 4,50 & 138-184 \\
\hline Legkisebb homloksz. - Min. front. b. (mm) ${ }^{\mathrm{a}}$ & 1217 & $111,74,55$ & $98-127$ & 1112 & 109,1 & 4,19 & 96-122 \\
\hline Járomívszélesség - Bizyg. breadth (mm) & 1217 & $145,95,70$ & $122-164$ & 1112 & 139,3 & 5,22 & $122-158$ \\
\hline Morf. arcmagasság - Tot. fac. height $(\mathrm{mm})^{\mathrm{c}}$ & 1217 & $121,36,4$ & 99-144 & 1112 & 111,8 & 5,5 & 93-128 \\
\hline zeglet sz. - Big. b. (mm) ${ }^{\mathrm{d}}$ & 1216 & $112,15,81$ & 95-132 & 1112 & 105,1 & 5,19 & $85-120$ \\
\hline Fejjel & 1217 & $84,83,28$ & $73,1-97,5$ & 1112 & 85,6 & 2,86 & $75,0-93,6$ \\
\hline Arcjelző - Facial index & 1217 & $83,24,87$ & $66,2-100,0$ & 1112 & 80,2 & 4,38 & $64,4-98,5$ \\
\hline Orrjelző - Nasal index & 1212 & $66,0 \quad 6,52$ & $46,9-89,6$ & 1111 & 65,3 & 6,10 & $47,3-90,0$ \\
\hline
\end{tabular}

${ }^{\mathrm{a}}$ : Legkisebb homlokszélesség - Minimum frontal breadth, ${ }^{\mathrm{b}}$ : Bizygomatic breadth, ${ }^{\mathrm{c}}$ : Morfológiai arcmagasság - Total facial height, d: Állkapocsszeglet szélesség - Bigonial breadth

A két nem között az aritmetikai átlagok alapján egyedül az állkapocs esetében találunk eltérést: a férfiak állkapcsa nagyon széles, a nőké széles. Az összes többi jelleg és index esetében azonos jellemzés adható (5. táblázat).

Az aritmetikai átlagok szerint az egyes minták jellemzése két kivétellel megegyezik az összevont mintánál megadott jellemzéssel. Az egyik eltérés a férfiak esetében az újkécskei minta arcjelzőjénél figyelhető meg, ahol az átlag egy egész értékkel nagyobb, és emiatt az arcuk középszélesnek jellemezhető. A másik eltérés a nők esetében ugyancsak az arcjelző átlagának az értékénél, az orgoványi mintánál tapasztalható, ami 0,1-del 
magasabb, mint az összevont minta átlaga, és emiatt arcuk jelző szerint a középszéles kategóriába sorolható. Mindkét esetben azonban olyan csekély az eltérés, hogy az gyakorlatilag elhanyagolható, statisztikailag nem igazolható. Ebből az a következtetés vonható le, hogy az egyes településeken megvizsgált személyek antropológiai méretei és megállapított jelzői alapján a népességek között nem mutatható ki semmilyen különbség.

A megállapított abszolút és relatív méreteket az egyes szerzők (Farkas 1973) által meghatározott kategóriákba nemek szerint besoroltuk (3-4. táblázat).

3. táblázat. Az összevont minta jellegeinek megoszlása kategóriák szerint - Férfiak. Table 3. Distribution of the traits by categories - Males.

\begin{tabular}{|c|c|c|c|}
\hline Kategóriák - Categories & $\mathrm{n}$ & Kategóriák (Categories) & $\mathrm{n}$ \\
\hline \multicolumn{2}{|l|}{ Termet - Stature $(\mathrm{cm})$} & \multicolumn{2}{|c|}{ Járomívszélesség - Bizygomatic breadth (mm) } \\
\hline $148,0-149,9$ & 1 & $122-127$ & 1 \\
\hline $150,0-159,9$ & 133 & $128-135$ & 33 \\
\hline $160,0-163,9$ & 228 & $136-143$ & 391 \\
\hline $164,0-166,9$ & 229 & $144-151$ & 611 \\
\hline $167,0-169,9$ & 211 & $152-165$ & 181 \\
\hline $170,0-179,9$ & 378 & Összesen - Total & 1217 \\
\hline $180,0-199,0$ & 32 & & \\
\hline Összesen - Total & 1212 & & \\
\hline \multicolumn{2}{|l|}{ Fejhossz - Head length $(\mathrm{mm})$} & \multicolumn{2}{|c|}{ Morfológiai arcmagasság - Tot. facial height (mm) } \\
\hline $151-169$ & 2 & $99-111$ & 82 \\
\hline $170-177$ & 37 & $112-117$ & 252 \\
\hline $178-185$ & 285 & $118-123$ & 433 \\
\hline $186-193$ & 648 & $124-129$ & 327 \\
\hline $194-212$ & 245 & $130-144$ & 123 \\
\hline Összesen - Total & 1217 & Összesen - Total & 1217 \\
\hline \multicolumn{2}{|l|}{ Fejszélesség - Head breadth (mm) } & \multicolumn{2}{|l|}{ Állkapocsszeglet szélesség - Bigonial breadth (mm) } \\
\hline $138-139$ & 2 & $93-98$ & 16 \\
\hline $140-147$ & 30 & 99-104 & 92 \\
\hline $148-155$ & 283 & $105-110$ & 378 \\
\hline $156-163$ & 674 & $111-132$ & 730 \\
\hline $164-178$ & 228 & Összesen - Total & 1216 \\
\hline Összesen - Total & 1217 & & \\
\hline \multicolumn{4}{|c|}{ Legkisebb homlokszél. - Min. frontal breadth (mm) Fejjelzö - Cephalic index } \\
\hline $96-105$ & 83 & $71,0-75,9$ & 5 \\
\hline $106-115$ & 900 & $76,0-80,9$ & 195 \\
\hline $116-127$ & 234 & $81,0-85,4$ & 575 \\
\hline \multirow[t]{3}{*}{ Összesen - Total } & 1217 & $85,5-90,9$ & 414 \\
\hline & & $91,0-97,0$ & 28 \\
\hline & & Összesen - Total & 1217 \\
\hline Morfológiai arcjelzö - Facial index & & Orrjelzö - Nasal index & \\
\hline $66,4-78,9$ & 244 & $46,9-54,9$ & 37 \\
\hline $79,0-83,9$ & 439 & $55,0-69,9$ & 872 \\
\hline $84,0-87,9$ & 328 & $70,0-84,9$ & 293 \\
\hline $88,0-92,9$ & 171 & $85,0-99,9$ & 10 \\
\hline $93,0-100,0$ & 35 & & \\
\hline Összesen - Total & 1217 & Összesen - Total & 1212 \\
\hline
\end{tabular}


Ezekből a megoszlásokból azt állapíthatjuk meg, hogy a méretek és indexek megoszlása mindkét nemnél eltéréseket mutat. A 3-4. táblázatban nemenként az egyes jellegek már jobban szóródnak, ugyanis ebben az esetben nem érvényesül az átlagnál említett tulajdonság, vagyis az, hogy az átlag elfedi a különbségeket.

4. táblázat. Az összevont minta jellegeinek megoszlása kategóriák szerint - Nők. Table 4. Distribution of the traits by categories - Females.

\begin{tabular}{|c|c|c|c|}
\hline Kategóriák - Categories & $\mathrm{n}$ & Kategóriák (Categories) & $\mathrm{n}$ \\
\hline Termet - Stature $(\mathrm{cm})$ & & \multicolumn{2}{|c|}{ Járomívszélesség - Bizygomatic breadth (mm) } \\
\hline $137,0-139,9$ & 1 & $121-127$ & 13 \\
\hline $140,0-148,9$ & 106 & $128-135$ & 246 \\
\hline $149,0-152,9$ & 212 & 136-142 & 565 \\
\hline $153,0-155,9$ & 205 & 143-158 & 288 \\
\hline $156,0-158,9$ & 227 & Összesen - Total & 1112 \\
\hline $159,0-167,9$ & 326 & & \\
\hline $168,0-168,9$ & 30 & & \\
\hline Összesen - Total & 1107 & & \\
\hline Fejhossz - Head length (mm) & & \multicolumn{2}{|l|}{ Morfológiai arcmagasság - Tot. facial height (mm) } \\
\hline 159-161 & 1 & $93-102$ & 46 \\
\hline $162-169$ & 19 & 103-107 & 198 \\
\hline $170-176$ & 229 & $108-113$ & 461 \\
\hline 177-184 & 605 & $114-119$ & 331 \\
\hline 185-201 & 258 & $120-128$ & 76 \\
\hline Összesen - Total & 1112 & Összesen - Total & 1112 \\
\hline Fejszélesség - Head breadth (mm) & & \multicolumn{2}{|c|}{ Állkapocsszeglet szélesség - Bigonial breadth (mm) } \\
\hline $135-141$ & 2 & $85-87$ & 1 \\
\hline $142-149$ & 199 & $88-93$ & 15 \\
\hline $150-157$ & 696 & 94-99 & 132 \\
\hline $158-184$ & 215 & $100-105$ & 421 \\
\hline \multirow[t]{2}{*}{ Összesen - Total } & 1112 & $106-120$ & 543 \\
\hline & & Összesen - Total & 1112 \\
\hline \multicolumn{2}{|l|}{ Legkisebb homlokszél. - Min. frontal breadth (mm) } & \multicolumn{2}{|l|}{ Fejjelzö-Cephalic index } \\
\hline 93-101 & 45 & $72,0-76,9$ & 2 \\
\hline $102-111$ & 773 & $77,0-81,9$ & 145 \\
\hline $112-122$ & 294 & $82,0-86,4$ & 597 \\
\hline \multirow[t]{3}{*}{ Összesen - Total } & 1112 & $86,5-91,9$ & 352 \\
\hline & & $92,0-94,0$ & 16 \\
\hline & & Összesen - Total & 1112 \\
\hline Morfológiai arcjelzö - Facial index & & \multicolumn{2}{|c|}{ Orrjelzö - Nasal index } \\
\hline $61,4-76,9$ & 236 & $47,3-54,9$ & 40 \\
\hline $77,0-80,9$ & 409 & $55,0-69,9$ & 833 \\
\hline $81,0-84,9$ & 312 & $70,0-84,9$ & 233 \\
\hline $85,0-89,9$ & 131 & $85,0-99,9$ & \\
\hline $90,0-98,5$ & 24 & Összesen - Total & 1109 \\
\hline Összesen - Total & 1112 & & \\
\hline
\end{tabular}


A 3-4. táblázatok adatai alapján a férfiakat és nőket a következők jellemzik:

Férfiak: a testmagasság túlnyomórészt magas, de jelentős számú a kisközepes, közepes és nagyközepes termetüek száma is. A fej hosszú, széles, homlokuk széles. Az arc széles és középmagas, az állkapocs nagyon széles. A relatív méretek eloszlása alapján fejük rövid (brachycephal), arcuk széles (euryprosop), orruk keskeny (leptorrhin).

Nők: a testmagasság főként magas, de jelentős számú a nagyközepes, kisközepes és közepes testmagasságúak száma is. Fejük hosszú, széles, homlokuk széles. Arcuk széles, középmagas. Az állkapocs széles. A relatív méretek szerint fejük rövid (brachycephal), arcuk széles (euryprosop), orruk keskeny (leptorrhin).

Ha a két nemről készült jellemzést összehasonlítjuk, kitünik, hogy csupán egy esetben van eltérés: a férfiak állkapcsa elsősorban nagyon széles, míg a nőké csak széles. Az összes többi esetben teljesen azonos a megoszlás, amiből azt a következtetést vonhatjuk le, hogy a férfiak és nők antropológiai szempontból teljesen hasonlóak.

5. táblázat. A vizsgált minták jellegeinek aritmetikai átlaga.

Table 5. Arithmetic mean of the traits in the examined samples.

\begin{tabular}{|c|c|c|c|c|c|c|c|c|c|}
\hline \multirow[b]{2}{*}{ Jelleg - Trait } & \multicolumn{9}{|c|}{ Település - Residence } \\
\hline & B & $\mathrm{F}$ & $\mathrm{O}$ & SzM & $\mathrm{SzSz}$ & Ó & $\mathrm{L}$ & $\mathrm{K}$ & Ú \\
\hline & \multicolumn{9}{|c|}{ Férfiak - Males } \\
\hline Testmagasság - Stature (cm) & 167,6 & 167,2 & 165,7 & 167,1 & 166,9 & 166,6 & 168,9 & 167 & 166,7 \\
\hline Legnagyobb fejhossz - Head length (mm) & 189,0 & 189,1 & 188,3 & 189,5 & 189,0 & 188,8 & 188,1 & 189,0 & 187,6 \\
\hline Legnagyobb fejszélesség - Head breadth (mm) & 158,2 & 159,0 & 158,7 & 157,5 & 158,6 & 160,8 & 159,4 & 158,3 & 158,6 \\
\hline Legkisebb homlokszél. - Min. frontal b. (mm) & 111,2 & 110,7 & 110,9 & 112,6 & 111,2 & 113,2 & 111,9 & 111.3 & 112,9 \\
\hline Járomívszélesség - Bizyg. breadth (mm) & 145,0 & 145,5 & 146,3 & 146,2 & 146,0 & 148,2 & 146,3 & 144,7 & 145,2 \\
\hline Morfológiai arcmagasság - Tot. fac. h. $(\mathrm{mm})^{\mathrm{c}}$ & 120,4 & 120,6 & 120,2 & 122,3 & 121,2 & 122,7 & 122,2 & 120,3 & 122,2 \\
\hline Állkapocsszeglet szélesség - Bigon. b. (mm) & 112,4 & 111,5 & 112,2 & 112,4 & 111,8 & 113,9 & 113,4 & 110,5 & 112,1 \\
\hline Fejjelző - Cephalic index & 83,6 & 83,0 & 84,6 & 83,3 & 83,0 & 85,3 & 84,9 & 83,7 & 84,4 \\
\hline Arcjelzö - Facial index & 83,1 & 83,0 & 82,3 & 83,6 & 83,0 & 82,8 & 83,6 & 83,2 & 84,2 \\
\hline Orrjelző - Nasal index & 66,0 & 65,7 & 65,8 & 66,9 & 66,4 & 66,2 & 65,7 & 65,2 & 65,9 \\
\hline \multicolumn{10}{|c|}{ Nök - Females } \\
\hline Testmagasság - Stature (cm) & 155,5 & 156,1 & 155,4 & 156,1 & 155,9 & 156,8 & 157, & 155 & 156,1 \\
\hline Legnagyobb fejhossz - Head length (mm) & 180,5 & 179,9 & 180 & 181,3 & 180,1 & 180,8 & 180,8 & 180, & 180,4 \\
\hline Legnagyobb fejszélesség - Head breadth (mm) & 152,9 & 153,6 & 153,6 & 154,1 & 153,4 & 154,6 & 154,9 & 152,9 & 152,7 \\
\hline Legkisebb homlokszél. - Min. frontal b. (mm) & 108,4 & 107,3 & 108,3 & 111,2 & 108,7 & 110,3 & 109,8 & 108,7 & 111,2 \\
\hline Járomívszélesség - Bizyg. breadth (mm) & 137,8 & 138,3 & 138,5 & 141,2 & 139,3 & 141,0 & 140,3 & 138,5 & 139,5 \\
\hline Morfológiai arcmagasság - Tot. fac. h. $(\mathrm{mm})^{\mathrm{c}}$ & 110,6 & 111,3 & 112,1 & 112,8 & 112,1 & 112,1 & 112,2 & 110,9 & 112,7 \\
\hline Állkapocsszeglet szélesség - Bigon. b. (mm) & 105,0 & 103,8 & 105,9 & 106,2 & 104,5 & 106,5 & 106,4 & 104,7 & 105,4 \\
\hline Fejjelzö - Cephalic index & 84,8 & 85,5 & 85,3 & 85,0 & 85,2 & 85,6 & 85,5 & 84,8 & 85,1 \\
\hline Arcjelző - Facial index & 80,4 & 80,5 & 81,0 & 80,0 & 80,5 & 79,6 & 80,0 & 80,1 & 80,9 \\
\hline Orrjelző - Nasal index & 66,1 & 64,8 & 64,7 & 65,4 & 64,2 & 66,4 & 66,5 & 65,0 & 65,8 \\
\hline
\end{tabular}

B: Bugac, F: Fülöpszállás, O: Orgovány, SzM: Szalkszentmárton, SzSz: Szabadszállás, Ó: Ókécske,

L: Lászlófalva, K: Kunszállás, Ú: Újkécske; ${ }^{a}$ : Legkisebb homlokszélesség - Minimum frontal breadth,

b: Bizygomatic breadth, ${ }^{\mathrm{c}}$ : Total facial height, ${ }^{\mathrm{d}}$ : Bigonial breadth

\section{Irodalom}

Farkas, L.Gy. (2016): Biológiai antropológiai ismeretek Kecskemétröl és környékéröl. Kecskemét Monográfiája (megjelenés alatt). 
Farkas, Gy. (1973): Antropológiai praktikum II. JATE, Szeged.

Henkey, Gy. (1961): Fülöpszállási kunok embertani vizsgálata. Népkutató Füzetek (Kecskemét), 2: $1-27$.

Henkey, Gy. (1962-63): Szabadszállási kunok embertani vizsgálata. Népkutató Kör Évkönyve. Városi Művelődési Ház, Kecskemét. pp. 30.

Mándoki, A. (1961): A szabadszállási Lenin Tsz tagjainak orvosi és embertani vizsgálata. Népkutató Füzetek (Kecskemét), 3: 3-10.

Levelezési cím:

Mailing address:
Farkas L. Gyula

Szegedi Tudományegyetem, Természettudományi és Informatikai Kar Embertani Tanszék

Közép fasor 52.

H-6726 Szegd

Hungary

farlgy@bio.u-szeged.hu 
